ENVIRONMENTAL

RESTORATION

PROGRAM

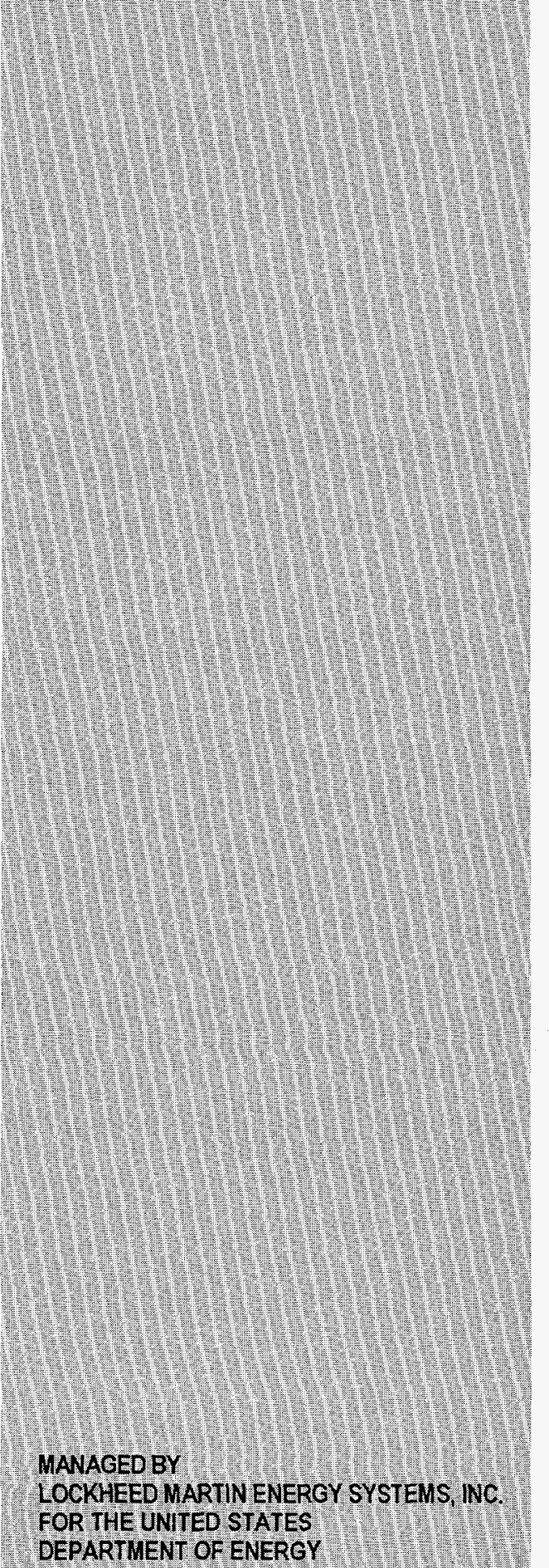

DEPARTMENT OF ENERGY

\section{Experimental Bypass of Lake Reality, Oak Ridge Y-12 Plant, Oak Ridge, Tennessee}

\section{RECEIVED \\ OCT 221997 \\ OSTI}

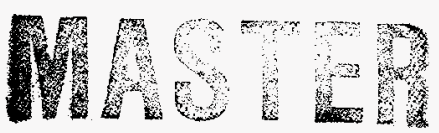

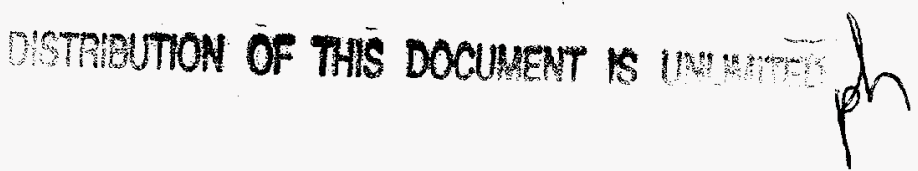

This document has been approved by the Y-12 Plant Technical Information Office for release to the public. Date: 1 \&LABPSTSTEMS

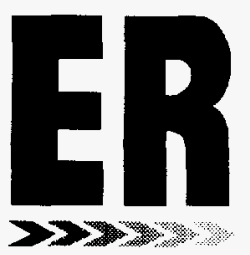




\title{
Experimental Bypass of Lake Reality, Oak Ridge Y-12 Plant, Oak Ridge, Tennessee
}

Date Issued-October 1997

\author{
Prepared for the \\ U.S. Department of Energy \\ Office of Environmental Management \\ under budget and reporting code EW 20 \\ Environmental Management Activities at the \\ OAK RIDGE Y-12 PLANT \\ Oak Ridge, Tennessee 37831 \\ managed by \\ LOCKHEED MARTIN ENERGY SYSTEMS, INC. \\ for the \\ U.S. DEPARTMENT OF ENERGY \\ under contract DE-AC05-84OR21400
}




\section{DISCLAIMIER}

Portions of this document may be illegible in electronic image products. Images are produced from the best available original docoment. 


\section{DISCLAIMER}

This report was prepared as an account of work sponsored by an agency of the United States Government. Neither the United States Government nor any agency thereof, nor any of their employees, make any warranty, express or implied, or assumes any legal liability or responsibility for the accuracy, completeness, or usefulness of any information, apparatus, product, or process disclosed, or represents that its use would not infringe privately owned rights. Reference herein to any specific commercial product, process, or service by trade name, trademark, manufacturer, or otherwise does not necessarily constitute or imply its endorsement, recommendation, or favoring by the United States Government or any agency thereof. The views and opinions of authors expressed herein do not necessarily state or reflect those of the United States Government or any agency thereof. 


\section{PREFACE}

The purpose of this report is to present a summary of the results of the Lake Reality Temporary

Bypass. This work was performed under Work Breakdown Structure 1.1.03.44 (Activity Data Sheet 2300, "Y-12 RA"). 


\section{CONTENTS}

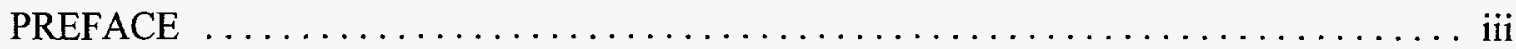

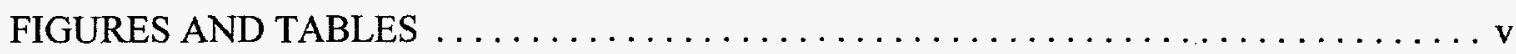

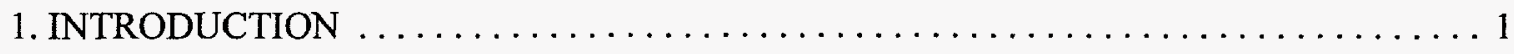

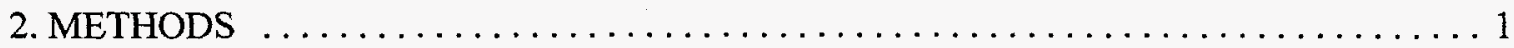

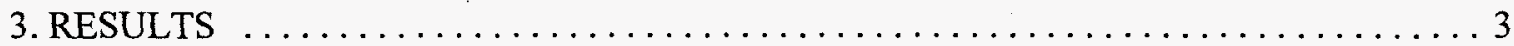

3.1 EFFECT ON CONCENTRATION/LOADING AT STATION $17 \ldots \ldots \ldots \ldots 3$

3.2 EFFECT ON METHYLMERCURY AT STATION $17 \ldots \ldots \ldots \ldots \ldots \ldots . \ldots$

3.3 EFFECT OF REDUCED MERCURY INPUT ON MERCURY IN LAKE REALITY $\ldots \ldots \ldots \ldots \ldots \ldots \ldots \ldots \ldots \ldots \ldots \ldots \ldots \ldots \ldots \ldots \ldots \ldots$

3.4 EFFECTS ON LAKE REALITY FISH COMMUNITY $\ldots \ldots \ldots \ldots \ldots \ldots \ldots 7$

3.5 EFFECTS ON BIOACCUMULATION OF MERCURY AND PCBS $\ldots \ldots \ldots \ldots 8$

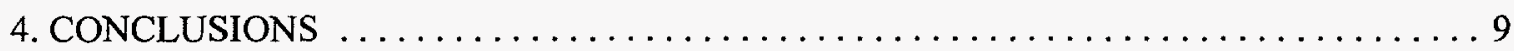

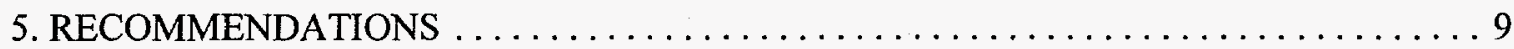




\section{FIGURES}

1. Siphon array that bypasses flow of East Fork Poplar Creek around Lake Reality . . . . . . 2

2. Regressions of mercury concentration in East Fork Poplar Creek at Station 17 vs time,

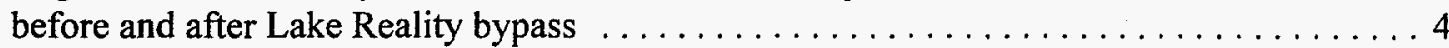

3. Average methylmercury concentration at sites in East Fork Poplar Creek, before and after Lake Reality experimental bypass $\ldots \ldots \ldots \ldots \ldots \ldots \ldots \ldots \ldots \ldots \ldots \ldots \ldots \ldots$

4. Methylmercury in East Fork Poplar Creek at Y-12, before and after Lake Reality bypass . . 7

5. Mean mercury concentrations in redbreast sunfish in upper East Fork Poplar Creek before and after Lake Reality bypass

\section{TABLES}

1. Changes in mercury transport and bioaccumulation associated with the experimental Lake Reality bypass .5 


\section{INTRODUCTION}

Studies conducted by the Y-12 Reduction of Mercury in Plant Effluent (RMPE) Program and Y-12 Biological Monitoring and Abatement Program (BMAP) in 1995 and 1996 (Y/ER-251, Y/ER-277) identified concerns regarding Lake Reality's effect on the transport and transformation of mercury in East Fork Poplar Creek (EFPC). The pond appeared to have two potentially adverse effects on mercury transport. First, it acted as a biochemical reactor, converting inorganic mercury in inflowing water to methylmercury, a more toxic substance with extremely high bioaccumulation potential in aquatic environments. Second, the pond appeared to trap mercury associated with suspended particulates during periods of stormflow, and slowly released that mercury via the export of resuspended particles during periods of baseflow. The net effect was to raise the day-to-day exposure of aquatic life to mercury in the stream downstream from the pond, and add to the calculated mercury loading of the stream under baseflow conditions.

Lake Reality plays a beneficial role in the dispersion and retention of spills of toxic materials that may occur in the industrial site upstream, and also acts to buffer peak stormflow at downstream sites. When its predecessor, New Hope Pond, was replaced by Lake Reality, mercury concentrations in fish in the downstream reach decreased strikingly. Concentrations of both mercury and polychlorinated biphenyls (PCBs) are substantially higher in fish from EFPC upstream from Lake Reality, suggesting that the pond plays a role in reducing the accumulation of the chemicals in fish downstream from it. Hypothetical mechanisms through which Lake Reality could reduce mercury and PCB bioaccumulation include: altering food chain structure, increasing the association of contaminants with particulates, and impeding fish movement. Alternate explanations for the phenomenon that do not involve Lake Reality include rapid conversion of mercury or PCBs from dissolved to particle-associated forms in the creek above Lake Reality or the possibility that localized high concentrations of these substances in the streambed above Lake Reality dominate the exposure pathway to fish

Scientific investigations thus indicated that diversion of the flow of EFPC around Lake Reality had the potential to reduce time-averaged concentrations of methylmercury and total mercury in the creek below its discharge, but that such diversion might also interfere with possible beneficial effects of the retention pond. Therefore, an experimental bypass of the pond was undertaken in late 1996 to evaluate the consequences of such an action before embarking on a more permanent change.

\section{METHODS}

An array of six 8-in. siphons was installed at the downstream terminus of the Lake Reality distribution channel (Fig. 1). The siphon array was capable of conducting 8-10 mgd when configured to carry the maximum flow. Flow was controlled by butterfly valves on the siphon discharges and by varying the number of functioning siphons. 


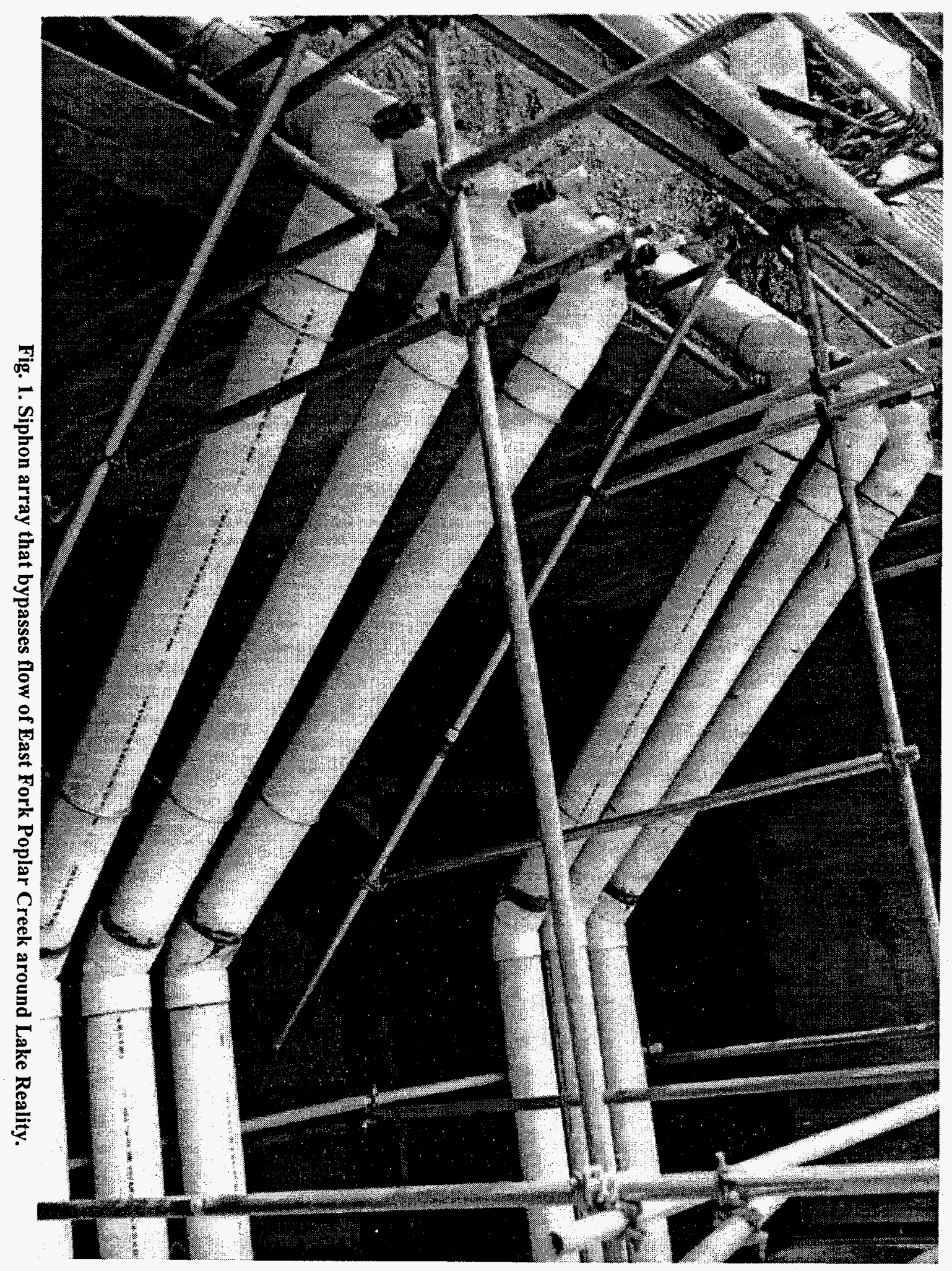


In practice, siphon flow varied much less with increased depth of water in the distribution channel than did flow through Lake Reality. Consequently, maintaining a controlled minimal flow through the pond proved to be difficult, and the proportion of flow and fraction of the time with more than $90 \%$ of the flow bypassing the lake was lower than hoped for. Nevertheless, over the period of intensive measurement (January-March 1997), approximately $75 \%$ of EFPC flow bypassed the pond, and bypass flow was greater than $90 \%$ of total streamflow $40 \%$ of the time.

Effects of the bypass were measured using existing monitoring programs wherever possible. Daily National Pollutant Discharge Elimination System (NPDES) monitoring of mercury concentrations and flow at Station 17 provided key information on mercury fluxes before and after the bypass. These data were augmented by RMPE Program measurements of mercury in water above, below, and within Lake Reality. Effects on methylmercury production were monitored by the existing RMPE Program studying longitudinal patterns of mercury speciation in EFPC associated with reductions in mercury inputs. The NPDES BMAP program monitored effects of the bypass experiment on bioaccumulation of mercury and PCBs in fish, and Oak Ridge National Laboratory staff in the Y-12 BMAP program assessed effects on fish communities in Lake Reality and EFPC.

\section{RESULTS}

\subsection{EFFECT ON CONCENTRATION/LOADING AT STATION 17}

Figure 2 and Table 1 illustrate the effects of the experimental bypass on total mercury concentrations at Station 17 (the monitoring point on the stream at the Y-12 boundary). Mean mercury concentration at this site was $0.80 \mu \mathrm{g} / \mathrm{L}$ in the 2 months preceding bypass, and $0.56 \mu \mathrm{g} / \mathrm{L}$ for the period following bypass. The difference in average mercury concentrations was similar to the expected contribution from Lake Reality.

In August 1996, the Flow Management Project was initiated in EFPC $2 \mathrm{~km}$ upstream from Lake Reality. This project stabilized the minimum flow in the stream at $7-8 \mathrm{mgd}$ at Station 17 by adding water from Melton Hill Reservoir. It had the effects of: 1) diluting instream mercury more than twofold; 2) resuspending additional mercury from sediments as a consequence of higher current velocities; and 3) increasing mercury inputs from unknown nonpoint sources (possibly subsurface water flows). The baseline period against which to evaluate the experimental bypass was therefore restricted to the 3-month period between the start of Flow Management and the start of the bypass. Data from the first month of Flow Management were not used because this was assumed to represent the period of most sediment resuspension. Similarly, the first month of bypass start-up was not included because of irregular operation of the siphon array during a learning phase of operation.

Figure 1 presented the regression of total mercury concentration ( $\log$ transformed to emphasize baseflow values) versus time for the before bypass and after bypass periods. In each case, there is a great deal of day-to-day variation and a slight negative slope, but the slopes of the linear regressions are statistically indistinguishable from zero. Each period appears to represent approximate steady state conditions, and the displacement between the two curves in December 1996 indicates the change in instream total mercury concentration to be $0.21 \mu \mathrm{g} / \mathrm{L}$. This corresponds to decreased loading of $5.3 \mathrm{~g} \mathrm{Hg} /$ day at a discharge rate of $7 \mathrm{mgd}$. 


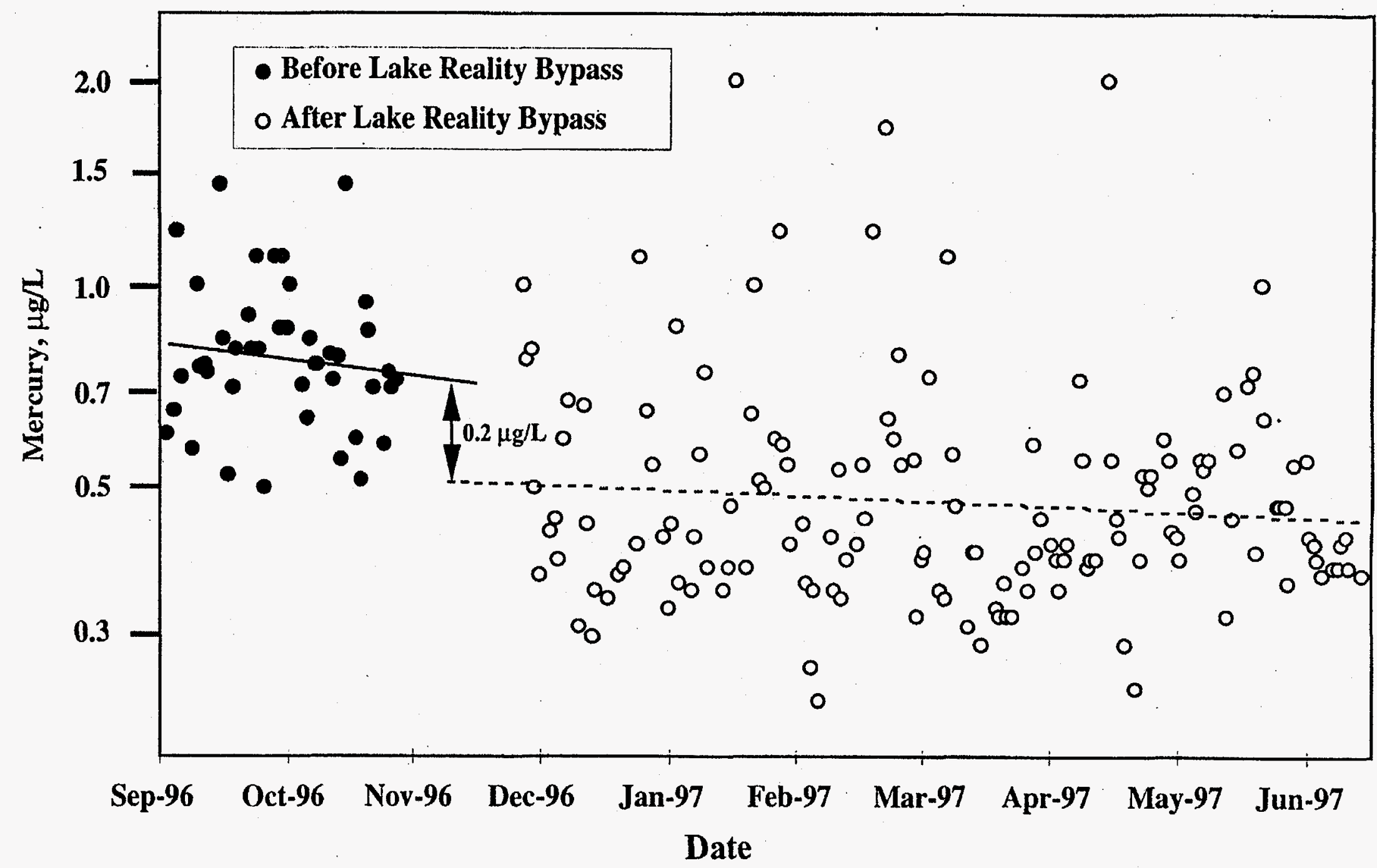

Fig. 2. Regressions of mercury concentration in East Fork Poplar Creek at Station 17 vs time, before and after Lake Reality bypass. Mercury concentrations log-transformed to improve agreement with statistical assumptions and to deemphasize influence of wet weather flows. 
Mean mercury loading at Station 17 for baseflow conditions $(<8 \mathrm{mgd})$ was $19.9 \mathrm{~g} / \mathrm{d}$ before the bypass, and $11.8 \mathrm{~g} / \mathrm{d}$ for the postbypass period (Table 1 ). When all flows are included, loading was 22.9 versus $17.0 \mathrm{~g} / \mathrm{d}$ for the pre and post bypass periods, respectively.

Table 1. Changes in mercury transport and bioaccumulation associated with the experimental Lake Reality bypass. Values are mean $\pm \mathrm{SE}$.

\begin{tabular}{|c|c|c|}
\hline & $\begin{array}{l}\text { Before bypass } \\
\text { (September-October 1996) }\end{array}$ & $\begin{array}{l}\text { After bypass } \\
\text { (December-June 1997) }\end{array}$ \\
\hline $\begin{array}{l}\text { Mercury concentration at Station } 17 \\
(\mu \mathrm{g} / \mathrm{L})\end{array}$ & $\begin{array}{l}0.80 \pm 0.03 \\
\mathrm{n}=43\end{array}$ & $\begin{array}{l}0.56 \pm 0.04 \\
n=144\end{array}$ \\
\hline $\begin{array}{l}\text { Mercury loading at Station } 17(\mathrm{~g} / \mathrm{d}) \\
\text { Flow }<15 \mathrm{mgd} \\
\text { Flow }<8 \mathrm{mgd}\end{array}$ & $\begin{array}{l}22.9 \pm 1.6(n=43) \\
19.9 \pm 0.8(n=38)\end{array}$ & $\begin{array}{l}17.0 \pm 2.5(n=135) \\
11.8 \pm 0.6(n=96)\end{array}$ \\
\hline $\begin{array}{l}\text { Methylmercury concentration at } \\
\text { Station } 17(\mathrm{ng} / \mathrm{L})\end{array}$ & $\begin{array}{l}0.52 \pm 0.03 \\
\mathrm{n}=2\end{array}$ & $\begin{array}{l}0.17 \pm 0.04 \\
\mathrm{n}=2\end{array}$ \\
\hline $\begin{array}{l}\text { Mercury concentration in Lake } \\
\text { Reality, }<0.5 \text { mgd flow out }(\mu \mathrm{g} / \mathrm{L})\end{array}$ & $\begin{array}{l}0.80 \pm 0.03^{*} \\
\mathrm{n}=43\end{array}$ & $\begin{array}{l}1.01 \pm 0.08 \\
\mathrm{n}=31\end{array}$ \\
\hline $\begin{array}{l}\text { Mercury concentration in fish, } \\
\mathrm{mg} / \mathrm{kg}(\mathrm{n}=6) \\
\text { Lake Reality } \\
\text { Station } 17 \\
\text { Above Lake Reality }\end{array}$ & $\begin{array}{l}0.76 \pm 0.04 \\
0.95 \pm 0.26 \\
1.45 \pm 0.14\end{array}$ & $\begin{array}{l}0.45 \bullet 0.03 \\
0.52 \pm 0.09 \\
1.22 \pm 0.10\end{array}$ \\
\hline $\begin{array}{l}\text { PCB concentration in fish, } \\
\mathrm{mg} / \mathrm{kg}(\mathrm{n}=6) \\
\text { Lake Reality } \\
\text { Station } 17 \\
\text { Above Lake Reality }\end{array}$ & $\begin{array}{l}1.68 \pm 0.41 \\
1.93 \pm 0.45 \\
1.95 \pm 0.08\end{array}$ & $\begin{array}{l}1.63 \pm 0.47(n=4) \\
0.86 \pm 0.18(n=5) \\
1.39 \pm 0.17\end{array}$ \\
\hline
\end{tabular}

*Station 17

\subsection{EFFECT ON METHYLMERCURY AT STATION 17}

Figure 3 depicts the role of Lake Reality as a generator of methylmercury. When EFPC flow provided a continuing source of reactive mercury to Lake Reality, methylmercury concentrations in the stream immediately downstream from the pond were many times higher than upstream. Under bypass conditions, that downstream increase was no longer evident. Mean methylmercury concentration in EFPC on the two postflow management dates prior to the bypass experiment was $0.52 \mathrm{ng} / \mathrm{L}$, and under bypass conditions it was threefold lower $(0.17 \mathrm{ng} / \mathrm{L}$, Table 1$)$.

Within Lake Reality, methylmercury concentrations remained at levels typical of prebypass conditions, averaging $0.65 \mathrm{ng} / \mathrm{L}$ in the postbypass period (Fig. 4). Methylmercury in water flowing into Lake Reality averaged $0.18 \mathrm{ng} / \mathrm{L}$ during the bypass, versus $0.22 \mathrm{ng} / \mathrm{L}$ in the prebypass period. This suggests that the fresh inputs of mercury delivered to Lake Reality by EFPC are not needed to sustain methylmercury production in the pond. The hypothesis that mercury in pond sediments is slowly converted to mercury sulfide and rendered less biologically available than mercury freshly sorbed by suspended particles is not supported by these observations. One concern about the pond bypass was that with the reduction in flushing of the pond, methylmercury would accumulate to high 

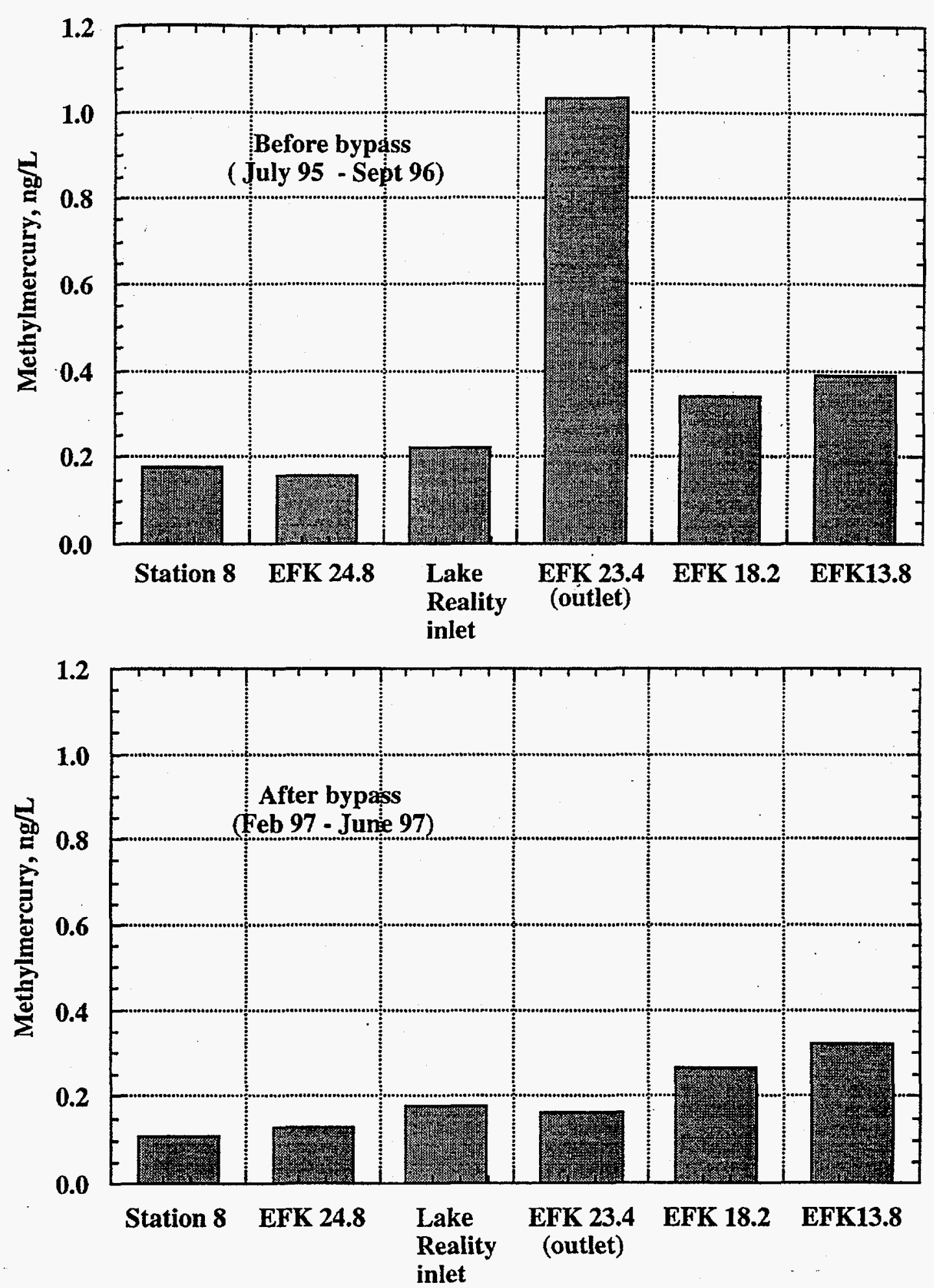

Fig. 3. Average methylmercury concentration at sites in East Fork Poplar Creek, before and after Lake Reality experimental bypass. 
concentrations in the water column and be released to EFPC during high flow. The observation that methylmercury in Lake Reality during the bypass did not exceed prebypass concentrations indicates that this concern is unwarranted.

\subsection{EFFECT OF REDUCED MERCURY INPUT ON MERCURY IN LAKE REALITY}

Total mercury concentration in the water column in Lake Reality is determined by the rate of mercury input from inflow and resuspension, the rate of washout at the spillway, and the rate of sedimentation of mercury associated with particulates. Depending on the relative rates of these processes, the response to reducing flow through the lake could be an increase, decrease or no change in waterborne mercury concentration. Over the course of the Lake Reality bypass experiment, mercury in Lake Reality showed little change, averaging $1.0 \mu \mathrm{g} / \mathrm{L}$ during the experiment and $0.8 \mu \mathrm{g} / \mathrm{L}$ prior to bypass (Table 1). This demonstrates the importance of resuspension of

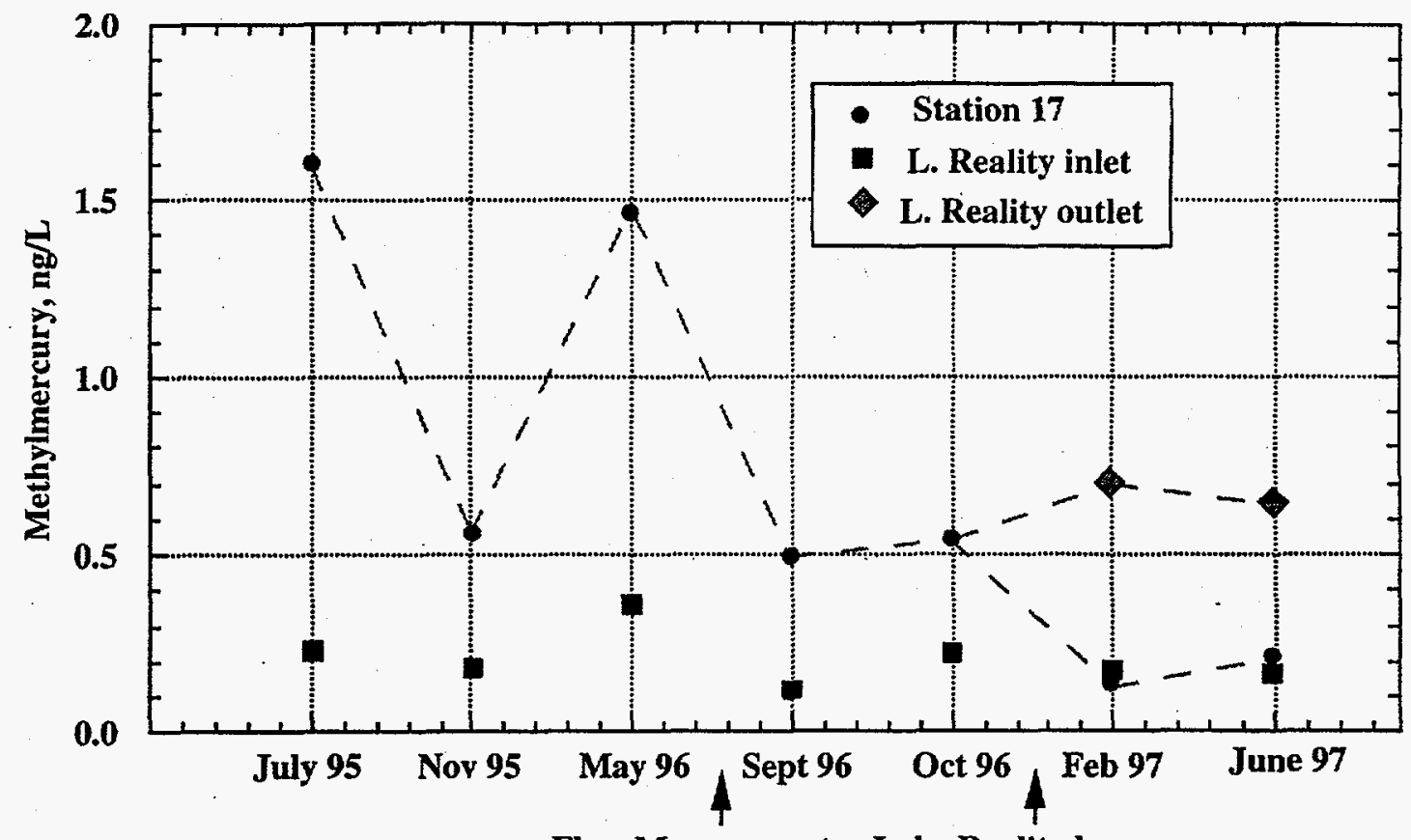

Flow Management Lake Reality bypass

Fig. 4. Methylmercury in East Fork Poplar Creek at Y-12, before and after Lake Reality bypass.

mercury-laden particles within the pond in maintaining mercury in the water column and is consistent with the view of the pond as a temporary storage site for particle-associated mercury, from which it is gradually released to the stream.

\subsection{EFFECTS ON LAKE REALITY FISH COMMUNITY}

The fish community of Lake Reality was surveyed in spring 1996 by BMAP staff at ORNL. Semiquantitative sampling showed the fish population to show no adverse effects associated with the bypass experiment. Catch-per-unit effort was typical of expectations, and all species usually found in the pond were represented. The large fish kill of July 1997 in EFPC above Lake Reality did 
not appear to affect fish within the pond, providing further evidence that the fish community in the pond is not stressed by the reduction in water turnover.

Improvements in water quality associated with flow management continued to be evident in the fish population at Station 17 in 1997, indicating that the reduction in organic export from Lake Reality did not have a negative impact on species richness in the fish community downstream from the pond. Carrying capacity of the reach of stream immediately below Lake Reality might be expected to fall with the reduction in food inputs from the pond discharge, but such a change could further enhance opportunities for greater species richness. Species richness is the main measure in which this site falls below conditions typical of reference sites.

\subsection{EFFECTS ON BIOACCUMULATION OF MERCURY AND PCBS}

Mean mercury concentration in sunfish in EFPC at Station 17 decreased from 0.87 to 0.52 $\mathrm{mg} / \mathrm{kg}$ in the 6 months following initiation of the experimental bypass (Table 1). The decrease follows an atypically high concentration observed in November 1996 (Fig. 5), but nevertheless represents the lowest average concentration observed in fish at this site since monitoring started in 1985. A substantial decrease was also observed in sunfish from Lake Reality over the same period. Mercury in sunfish from the stream above Lake Reality exhibited a proportionately smaller decrease.

Mean mercury concentrations in redbreast sunfish at Station 17 decreased 50\% (from 1.4 to $0.74 \mathrm{mg} / \mathrm{kg}$ ) in the year following replacement of New Hope Pond with Lake Reality in 1988. Mercury concentrations in fish in the stream $1.5 \mathrm{~km}$ above Lake Reality now exceed $1 \mathrm{mg} / \mathrm{kg}$. These observations lead to concerns that bypassing Lake Reality would restore conditions to a state similar to that existing prior to 1989 , with a consequent increase in mercury bioaccumulation at Station 17. No such change was observed, and the decrease following bypass was consistent with theoretical expectations based on decreased export of methylmercury from Lake Reality and lower day-to-day total waterborne mercury concentrations.

Changes in food web structure in EFPC associated with both Flow Management and Lake Reality bypass will likely take several years to become fully manifest, because many aquatic species reproduce only once a year. Because of the importance of the food web pathway in mercury bioaccumulation, lengthening of the aquatic food web would act to increase mercury accumulation in predators such as redbreast sunfish, and could act to counter some of the beneficial aspects of the Lake Reality bypass.

Average PCB concentrations in sunfish at Station 17 have typically been less than $50 \%$ that observed in fish from Lake Reality and EFPC upstream, suggesting that Lake Reality played an important role in sequestering PCBs and making them less available for accumulation in the aquatic food chain. Bypassing Lake Reality thus posed the possibility of causing an increase in PCB accumulation at Station 17. Preliminary results of PCB analyses of sunfish for the postbypass period indicate no such increase (Table 1).

For both mercury and PCBs, projections of future trends (several years) based on a single shortterm study (6-month bypass) carries considerable uncertainty. Although results to date show no adverse effects of bypass on bioaccumulation of either contaminant, the possibility that such effects will become evident in the future remains. 


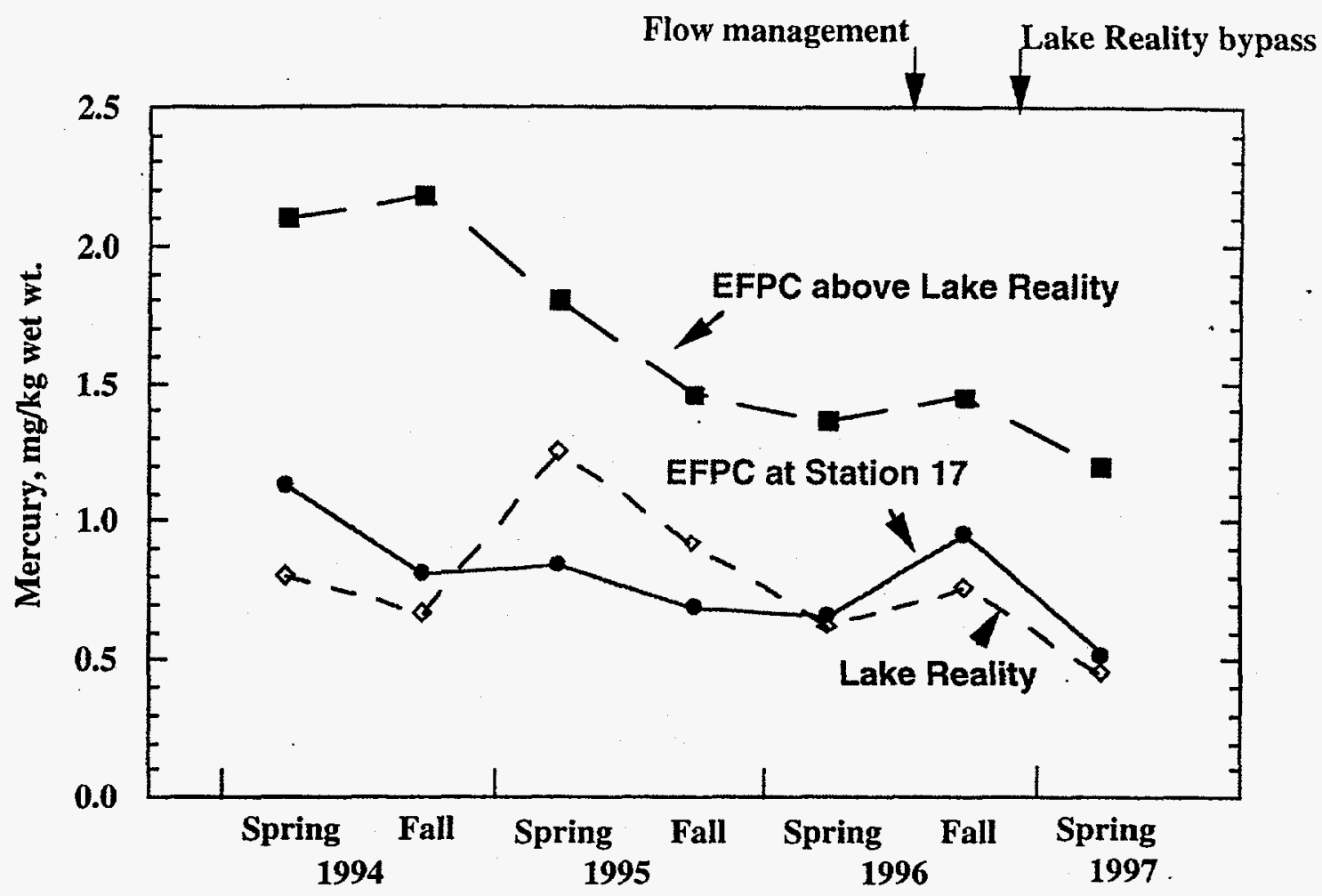

Fig. 5. Mean mercury concentrations in redbreast sunfish in upper East Fork Poplar Creek before and after Lake Reality bypass.

\section{CONCLUSIONS}

The experimental Lake Reality bypass achieved its goals of reducing baseflow mercury concentrations and loading in EFPC at Station 17, and of reducing waterborne methylmercury export to the creek downstream. Permanent bypass of Lake Reality has the potential to reduce dry weather mercury concentrations by approximately $200 \mathrm{ng} / \mathrm{L}$ and mercury loading by approximately $5 \mathrm{~g} / \mathrm{d}$. The magnitude of those reductions was close to expectations despite less than optimal performance of the bypass system because of atypically high precipitation throughout most of the experiment. None of the hypothesized adverse effects of the bypass proved to be a concern. Fish populations in Lake Reality were not demonstrably affected by reduced flow through the pond. Neither PCB nor mercury accumulation in fish increased as a result of the bypass, and both in fact decreased over the course of the experiment. Methylmercury did not increase to high levels in the flow-isolated Lake Reality.

\section{RECOMMENDATIONS}

The temporary bypass of Lake Reality through a siphon array was effective, but required substantial operational support and did not bypass high flows. The bypass of Lake Reality should continue, with changes in design recommended to improve the effectiveness of the bypass and to reduce the need for maintenance and support. Such changes should be implemented in time to be operational to help achieve the December 1998 goal of 5 g/d average dry weather mercury loading 
at Station 17. Lake Reality should remain in place as a spill retention/dispersion safeguard. The bypass experiment showed that occasional discharge through Lake Reality does not severely compromise the effectiveness of the bypass in achieving mercury transport goals. Because only long-term observation will determine conclusively if potential negative effects of the bypass on bioaccumulation are inconsequential, the design changes should incorporate the ability to inexpensively restore the system to its original function (full flow through Lake Reality).

One remaining concern regards the elimination of fish access to EFPC above Lake Reality except during periods of exceptionally high flow. This will impede the establishment of a diverse assemblage of fish in that reach, and may cause this biological indicator of water quality to make ecological conditions in the stream appear to be more affected by Y-12 discharges than they in fact are. If it is desired that fish diversity above Lake Reality achieve levels consistent with improvement in water quality, introductions of pollution-sensitive species may be required. 


\title{
DISTRIBUTION
}

\author{
1. L. V. Asplund \\ 2. M. A. Bogle \\ 3. E. T. Collins \\ 4. C. S. Haase \\ 5-9. J. F. Hensley \\ 10. S. L. McDonald \\ 11. H. C. Newsom \\ 12. P. T. Owen \\ 13. M. J. Peterson \\ 14. L. B. Raulston \\ 15. M. G. Ryon \\ 16. G. R. Southworth \\ 17. R. C. Woods, Jr. \\ 18. File-EMEF DMC-RC \\ 19. J. A. Johnston, TN \& Associates, 101 N. Rutgers Avenue, Suite 202, Oak Ridge, \\ Tennessee 37830 \\ 20. R. J. Sams, Jacobs Engineering Group, 105 Broadway Avenue, Oak Ridge, \\ Tennessee 37830 \\ 21. R. R. Turner, Frontier Geosciences, 414 Pontius Avenue North, Seattle, \\ Washington 98109
}

